\title{
Analysis on the Theoretical Origin of "Human Destiny Community" From the Perspective of Marxism
}

\author{
Yufei Wu ${ }^{a}$, Qiuyun Wu ${ }^{b}$ \\ School of Marxism, Guangxi Normal University, Guilin 541000, China. \\ a1692840468@qq.com, b535991402@qq.com
}

Keywords: Human Destiny Community; World view of history; Real community.

\begin{abstract}
The idea of "the community of human destiny" was first put forward in the 18th National Congress of the Chinese Communist Party. It is a result of the combination of Marxist theory and the practice of socialism with Chinese characteristics. This idea not only inherited the outstanding traditional cultural connotation of China, but also learned its most fundamental theoretical content from the Marxist theory. The theoretical origin of the analysis comes from three levels: the "material unity" theory at the philosophical level, the "world view of history" at the world view level, and the "real community" thought at Marx's theoretical level.
\end{abstract}

\section{Preface}

Since the "human destiny community" idea was clearly put forward in the report of the party's 18th National Congress, it has become the new darling of Secretary Xi's diplomacy and has delivered ideas in many important diplomatic occasions. General Secretary Xi has mentioned in the report of the 19th CPC National Congress that he calls on all peoples to work together to build a community of human destiny and build a beautiful world together. The "human destiny community" thought is our Party's emphasis on the crisis faced by mankind. It also formulates China's wisdom into a Chinese program and provides opinions for the peaceful development of the world and the happy life of all mankind. The idea of "human destiny community" inherits and innovates the idea of the "community" of the Marx and Engels,"community" originated from ancient Greece.

\section{Conceptual Elaboration}

\section{1 "Community" and "Community of Fate".}

The concept of "community" originated from the ancient Greek period. "Koinonia" was interpreted as a citizen group in the city-state; Cicero's community originated from "Communitas" and has now developed into the meaning of "Community" community and community in modern English; Marx chooses the word "Gemeinwesen" to correspond to it, referring to the non-political united form [9].The German scholar Ferdinand Tennis explained the meaning of "community" from the perspective of sociology. Members not only have a common living area, but also use shared culture and concepts as a bridge to build members' long-term identity with the community [10]. To sum up the three commonalities of "community" : firstly, there is a certain commonality among members; Secondly, there is a common sense and identity among the members; Finally, it is necessary to maintain the system and norms among the members.

The theory of "Community Peace" in the theory of international relations is the basis of the theory of the "fate community." The main body is set as a nation. Through fostering the sense of collective identity of members, mutual trust is formed, and international disputes are resolved peacefully, leading to a peaceful and stable order. The use of collective identity as a means to ease the predicament among member states, through the interaction to change the distrust between members. The concept of "destiny community" in our country pays more attention to the sense of identity among the member countries, promotes trust among countries by means of practical interaction, and raises 
the concept of common prosperity, symbiosis and consensus, and constructs a peaceful international environment.

\subsection{The Meaning and Development of the "Human Destiny Community".}

The concept of "community of human destiny" in China is the combination of symbiosis and common interest, which will form a new mode of development of reasonable symbiosis based on the common interests and collective identity of the countries. The concept of the "human fate community" put forward by the party's 18th National Congress was defined in the report as: "When pursuing national interests, considering the legitimate concerns of other countries, and promoting the common development of all countries in the pursuit of national development." It can be concluded that our country focuses on under the conditions of common development, based on the concept of win-win cooperation, the interests of participating countries will be realized. The content includes the concept of international power, common interest, sustainable development and global governance concept.

The "community of human destiny" was put forward in the 2011 white paper on the peaceful development of China. And was clearly advocated by the Party,s 18th National Congress.In 2014-2015 years, both Xi Jinping and Li Keqiang proposed to build a "Asian destiny community", proposed the construction of China-Pakistan "bilateral fate community" in Pakistan, and pointed out in Indonesia that the development of a "human destiny community"; until the party's 19th, it is pointed out that it is necessary to promote the construction of a human fate community.

\section{The Theoretical Origin of the "Community of Human Destiny"}

\subsection{Philosophical Foundation: the Unity of World Matter.}

The old saying goes: "The differences between the objects are not the same, and the things are also."Everything in the world is different, that is, the laws of nature and the objective laws of things.

First, the natural geographical distribution of countries around the world is different. With the deepening of globalization, the development of electronic information technology and transportation, multi-dimensional contacts between countries have become increasingly frequent and have gradually become an integral whole. From a cultural point of view, China has a history of 5,000 years of civilization while India is characterized by cultural diversity and complex religion. Although cultures have their merits and demerits, they are all common human spiritual wealth. Third, in the political system, the world currently has a capitalist system and a socialist system. However, due to differences in the development of various countries, even if they are the same capitalist countries, their own internal systems are not the same. In the end, the economic system, in the high development of economic globalization, no matter whether it is planned economy or market economy, the economy of any country can not develop independently.

The world we live in is both infinitely diverse and united. Finding the common values and interests of all mankind in a complex and varied world is precisely what it means to build a community of human destiny. The philosophical foundation is the material unity of the world.

\subsection{The Foundation of World View: Marx's View of World History.}

In the middle of the nineteenth Century, the history of the world was called "world history" by Marx. This concept was first appeared in the works of "German Ideology". Its central idea is that the development of social productivity makes the country no longer a single history and becomes a unified world history. The transformation of history to the world history, the regional turning to the world, and the foundation of the world view of the "community of human destiny", provides a new idea and a new plan for the survival and development of mankind under the background of globalization. With the linkage and promotion of economy, network and transportation, every country has gradually formed a community. No country can leave the world and grow independently. Peaceful development is the characteristics of the times in today's world development, but there are still such unstable situations in the Middle East, which seriously hinder the peaceful development of the world. 


\subsection{Theoretical Basis: Marx's Thought of "Real Community".}

The process and characteristics of the "real community". The community of Marx experienced three stages from the "nature" to the "virtual" to the "real" community. The low productivity of ancient societies, the common face of natural disasters, and the invasion of beasts, depend on the collective strength of individual survival. In this community, people are pursuing the common interests of the community rather than the individual's own interests, and they can also regard their own interests and public interests as the same. With the development of social productive forces, the capitalist system has entered the stage of history and the "unreal community" has emerged, that is, the social form in which one class rules another. In the "Communist Manifesto", Marx pointed out that "in place of the old bourgeois society with class and class opposition, it will be such a consortium, where everyone's free development is a condition for the free development of all people [11]." What is said here is the "combination of free people", "Assoziation" in German, and "Association" in modern English, referring to "association". In "Assoziation", the autonomy and freedom of the individual are the main ones. The "association" itself is not for controlling individual freedom, but for individuals to fully enjoy their independence and freedom [12]. The "real community" has the following characteristics: First, the public ownership of the means of production. Second, distribution according to need. Third, the class disappears. Fourth, the country,s demise.

\section{Conclusion}

The "real community" constructed by Marx is under the communist social system, the goal of win-win and win-win results advocates the sharing of human destiny community. The "community of human destiny" contains the ideas of building and sharing, inclusive and reciprocal, and taking the whole human perspective, carrying out the realistic conditions for the free development of human beings in all aspects of the whole field, and inheriting the theory of Marx.

\section{References}

[1]. Zhao Dixie. Marx's view of world history and its enlightenment in contemporary times.[J] Legal System and Conference.2017(5).

[2]. Xian Xiaoguang, Chen Xinjiang, characteristics and value criteria of the concept of "fate community". [J] Public Diplomacy Quarterly 2016 (12).

[3]. $\mathrm{Cu}$ Jin, Goo Chu. Differentiation of the concept of "fate community". Strategic decision research.[J].2016(6)

[4]. Zhou Wended, Lin Meaning, Zhao Jinke. The scientific connotation and great significance of Xi Jinping's thought of "human destiny community"-Based on the Marxist theoretical perspective. [J] Theoretical Issue. 2017 (1)

[5]. Fu Zeya. The scientific connotation and era character of the "human destiny community" - from the perspective of Marx's true community idea[J] Journal of Hubei Administration Institute.2017(1)

[6]. Jiao Han. The background and significance of Xi Jinping's idea of human destiny community. [J]Daring Social Sciences.2017 (6).

[7]. Kang Hushing, Chen Binue. "The Human Destiny Community": Marx's "Real Community" [J] Thoughts in Contemporary China. 2016(11).

[8]. Cu Guy. Xi Jinping's construction of the "human destiny community" theoretical source and value discussion. [J] and knowledge. 2017 (9).

[9]. Ma Junfeng. Research on the Marxist social community theory[M]. Beijing: China Social Sciences Press, 2011. 
[10]. [German] Ferdinand Tennis (translated by Lin Rongyuan). Community and society. The basic concept of pure sociology[M]. Beijing: Peking University Press.2010

[11]. Marx, Engels. Marx and Engels Selected Works: Volume I [M]. Beijing: People's Publishing House, 2012. 422.

[12]. Li Yongjie, Qi Shujun. The Conceptual Examination of Marx's Community and Interpretation of the Times. [J] Journal of Hubei University(Philosophy and Social Sciences)2017(4). 